\title{
Abnormalities of Lymphocyte Subsets Are Correlated With Concentrate Consumption in Asymptomatic Italian Hemophiliacs Treated With Concentrates Made From American Plasma
}

\author{
P.M. Mannucci, A. Gringeri, M. Ammassari, and Daniela Mari \\ A. Bianchi Bonomi Hemophilia and Thrombosis Centre and Third Institute of Clinical \\ Medicine, University of Milano, Italy
}

\begin{abstract}
Eighty-three symptom-free hemophiliacs were studied clinically, serologically, and by in vitro tests for cellular immunity in a geographical area in which AIDS has not yet been encountered despite the exclusive use of concentrates manufactured from American sources of plasma. Some patients showed the following abnormalites: lymphopenia $(4 \%)$, decreased $\mathrm{T}$-helper/T-suppressor $(\mathrm{Th} / \mathrm{Ts})$ cell ratios $(49 \%)$, or both abnormalities $(2 \%)$. Low $\mathrm{Th} / \mathrm{Ts}$ were mostly due to absolute or, less frequently, relative increases in Ts cells. The prevalence rates for these abnormalites were the same in patients treated with factor VIII or factor IX concentrates. There was an association between the higher Ts and lower Th cells counts and the low Th/Ts ratios and greater annual consumption of factor VIII and factor IX concentrates. These results support the view that protein load might be an important pathogenetic factor in lymphocyte abnormalities in symptom-free hemophiliacs.
\end{abstract}

Key words: acquired immune deficiency syndrome, hemophilia, plasma concentrates, lymphocyte populations, T-helper lymphocytes, T-suppressor lymphocytes.

\section{INTRODUCTION}

Within the past few years a previously undescribed syndrome has been diagnosed in more than 4,000 individuals in the United States and the morbidity rate is continuously increasing [1-5]. This syndrome, called acquired immune deficiency syndrome (AIDS), is associated with a severe failure of the body's immune sytem. Accordingly, the patient may develop rare malignancies and contract opportunistic infections, with an extremely high mortality rate. When reviewing the patient groups, about $75 \%$ were found to be homosexual, $17 \%$ intravenous drug users, $5 \%$ Haitians, and $1 \%$ are hemophiliacs [1-5]. In hemophiliacs, the risk of AIDS seems to be related to treatment with concentrates, either by transmission of virus(es) contained in these preparations manufactured from very large plasma pools or by chronic exposure to multiple protein antigens and immune complexes that can depress the immune response and facilitate opportunistic infections [6]. Neither of these mechanisms has yet been fully proven. The key laboratory abnormality in hemophiliacs (or other patient

Received for publication November 2, 1983; accepted February 16, 1984.

Address reprint requests to P.M. Mannucci, Via Pace 9, 20122 Milano, Italy.

(c) 1984 Alan R. Liss, Inc. 
groups) who have opportunistic infections is a marked decrease in circulating $\mathbf{T}$ lymphocyte predominantly due to low $\mathrm{T}$-helper lymphocytes and resulting in very low $\mathrm{T}$-helper (h)/T-suppressor(s) ratios [1-6]. However, several studies have also shown a high prevalence of abnormalities of lymphocyte subsets in symptomless hemophiliacs from the United States [7-14], the United Kingdom [15-17], Australia [18], and Austria [19]. In these patients, the low $\mathrm{Th} / \mathrm{Ts}$ ratios are usually due to an absolute or relative augmentation of Ts rather than to low absolute Th numbers as in patients with overt AIDS.

In Italy, hemophiliacs are treated either with the same commercial concentrates used by American hemophiliacs or with a concentrate manufactured in Austria from plasma mainly obtained from American donors by plasmapheresis. Therefore, they should theoretically be exposed to the same risk of contracting AIDS. A recent (1984) survey of 20 hemophilia centers made by the Italian Hemophilia Foundation has detected no case of opportunistic infection or malignancy among 2,350 of the 2,700 hemophiliacs estimated to live in this country. Only three patients persistently had unexplained generalized lymphadenopathy, which is suspected to be prodromal of, or associated to, AIDS but the relationship is still unclear [14,19,20]. We thought that the peculiar situation of hemophilia care in Italy, a geographical area in which AIDS has not yet been seen in hemophiliacs despite patients's exposure to USA sources of plasma, justified a study of T-lymphocyte subsets and other hematological parameters in an unselected group of 83 hemophiliacs coming for their annual check-ups at our center. We found that these patients, albeit asymptomatic, had a high prevalence of low $\mathrm{Th} / \mathrm{Ts}$ ratios that were mainly due to an absolute increase in Ts cell counts; that the abnormality was present equally in patients treated with factor VIII or IX concentrates, and was correlated with the amount of the concentrates used by the patient in the year preceding examination.

\section{PATIENTS AND METHODS}

\section{Patients}

The study population consisted of 83 consecutive hemophiliacs (64 with hemophilia A, 19 with hemophilia B) who came to the Hemophilia and Thrombosis Center for routine screening from March to June 1983. On each study day, healthy volunteer members of the laboratory staff and their parents and children were also studied, to have controls over the same age range (totaling 31). The clinical team filled in for both patients and controls detailed confidential questionnaires about personal and medical history, including drug exposure and sexual behaviour. The same doctors then examined all subjects, looking in particular for infection, lymphadenopathy, skin manifestations, or malignancy. All subjects were identified by numbers and the laboratory teams were unaware of clinical details.

Information on type and intensity of replacement therapy in the past year (1982) was obtained from hospital records or from the patient's records for those on home therapy (60\% of all patients). All patients were managed on the basis of "on demand" replacement therapy, but three patients had had short courses (6-8 weeks) of prophylactic therapy for the management of chronic synovitis. In our center, the average annual consumption of factor VIII concentrates per patient in the year before the study (1982) was 28,000 I.U. for hemophilia A and 16,000 for hemophilia B. 
Patients used exclusively commercial concentrates, manufactured from large plasma pools (for hemophilia A, Koate Cutter, Hemophil Hyland, and Kryobulin Immuno: for hemophilia B, Bebulin Immuno and Konyne Cutter). Amounts used in 1982 resembled closely the amounts of treatment given in the previous years. The majority of patients used more than one commercial brand, making it impossible to divide them according to source of concentrates used.

The 83 hemophiliacs were divided according to age, type and severity of hemophilia, intensity of treatment in the year before testing, positive or negative for HBV markers (HBsAg and anti-HBs) and serum levels of alanine transferase (ALT) (lower than $50 \mathrm{U} / \mathrm{L}$, between 50 and 100 and higher than 100). (Table I).

\section{Methods}

The total white blood cell, lymphocyte, and platelet counts were determined with a Coulter S Plus counter. Total T, Th, and Ts phenotypes were defined by means of immunofluoresence with monoclonal antibodies OKT3, OKT4, and OKT8 (Ortho Diagnostic System, Milan). Fluorescent cells were counted by a fluorescence-activated cell sorter (Spectrum, Ortho). We detected HBs Ag and anti-HBs by means of

TABLE I. Clinical and Laboratory Variables for 83

Asymptomatic Hemophiliacs

\begin{tabular}{|c|c|c|}
\hline & No. & Percent of total \\
\hline \multicolumn{3}{|l|}{ Age } \\
\hline$<10 \mathrm{yr}$ & 21 & 25 \\
\hline $10-20$ & 19 & 23 \\
\hline $21-30$ & 20 & 24 \\
\hline $31-60$ & 23 & 28 \\
\hline \multicolumn{3}{|l|}{ Type of hemophilia } \\
\hline Hemophilia A & 64 & 76 \\
\hline Hemophilia B & 19 & 24 \\
\hline \multicolumn{3}{|l|}{ Severity of hemophilia: } \\
\hline Factor VIII $<1 \%$ & 56 & 67 \\
\hline$" 11-5 \%$ & 1 & 1 \\
\hline$" \prime \prime>5 \%$ & 7 & 8 \\
\hline Factor IX $<1 \%$ & 14 & 17 \\
\hline " " $1-5 \%$ & 3 & 4 \\
\hline$" \quad>>5 \%$ & 2 & 3 \\
\hline \multicolumn{3}{|l|}{ Intensity of treatment } \\
\hline Untreated & 21 & 25 \\
\hline$<20,000 \mathrm{U} / \mathrm{yr}$ & 24 & 29 \\
\hline $20,000-40,000$ & 18 & 22 \\
\hline$>40,000$ & 20 & 24 \\
\hline \multicolumn{3}{|l|}{ Markers for hepatitis B } \\
\hline $\mathrm{HBsAg}+$ & 3 & 4 \\
\hline Anti-HBs and/or anti $\mathrm{HBc}+$ & 61 & 73 \\
\hline \multicolumn{3}{|l|}{ Alanine transferase } \\
\hline$<50 \mathrm{U} / \mathrm{L}$ & 57 & 69 \\
\hline $51-100 \mathrm{U} / \mathrm{L}$ & 15 & 18 \\
\hline$>100 \mathrm{U} / \mathrm{L}$ & 11 & 13 \\
\hline
\end{tabular}


radioimmunoassay (Austria II and AUSAB, Abbott Laboratories). We have defined as abnormal all values of blood cells and lymphocyte subsets that were outside the normal laboratory range established in this hospital.

\section{Statistical Tests}

Contingency tables were evaluated by the one-side Fisher exact test. Analysis of variance and the Wilcoxon rank sum test were used for comparing nonparametric variables in different groups; the Spearman rank test was used to check correlations between nonparametric variables.

\section{RESULTS}

The breakdown of patients according to demographic, clinical, and serological variables is shown in Table I. The different age groups were equally represented and the prevalence of hemophilia A over hemophilia B was similar to that expected from the general prevalence of the diseases. Patients could be divided into four groups of similar size according to the intensity of treatment, expressed as total units of factor VIII and IX concentrates infused in the year preceding examination (U/yr). There were 13 patients with mild or moderate hemophilia A or B and 8 patients with severe hemophilia who received no treatment in the preceding year in the untreated group. The prevalence of patients with anti-HBs $(73 \%)$ is similar to that in our whole hemophilia population ( $80 \%)$, and was mainly ascribable to the treated hemophiliacs; the prevalence of mildly or grossly abnormal ALT is also similar to that of the whole population.

Leukopenia $\left(<4.0 \times 10^{9} / \mathrm{L}\right.$ ) was seen in three $(4 \%)$ of 83 asymptomatic hemophiliacs, thrombocytopenia $\left(<150 \times 10^{9} / \mathrm{L}\right)$ in nine $(11 \%)$ and lymphopenia $\left(<1.2 \times 10^{9} / \mathrm{L}\right)$ in four $(5 \%)$. Leukopenia and lymphopenia were very mild, the lowest counts being 3.9 and $0.9 \times 10^{9} / \mathrm{L}$ respectively; only one patient had moderately severe thrombocytopenia $\left(33 \times 10^{9} / \mathrm{L}\right)$, the next value being $80 \times 10^{9} / \mathrm{L}$. T lymphocytes $\left(<0.9 \times 10^{9} / \mathrm{L}\right)$ were low in six patients $(7 \%)$; Th low $\left(<0.5 \times 10^{9} /\right.$ $\mathrm{L})$, in ten patients $(12 \%)$; Ts low $\left(<0.3 \times 10^{9} / \mathrm{L}\right)$, in one patient only; Ts high $(<$ $\left.1.2 \times 10^{9} / \mathrm{L}\right)$, in 15 patients $(18 \%)$; Th/Ts ratios low $(<1.0)$, in 41 patients $(49 \%)$ (Figs. 1-3). Only one of the four patients with lymphopenia also had low Th count and Th/Ts ratio; six of the nine thrombocytopenic patients had low ratios; none of the three patients with leukopenia had a low ratio. There was an association between amount of concentrate used and abnormalites of lymphocyte subsets. Figure 1 shows that in healthy controls, untreated hemophiliacs, and hemophiliacs treated with $<$ $20,000 \mathrm{U} / \mathrm{yr}$, Th mean values did not differ; Th, however, were significantly lower in the 20,000-40,000 $\mathrm{U}$ and $>40,000 \mathrm{U}$ treatment subgroups $(\mathrm{P}<0.005)$, with no significant difference between the last two subgroups. The Ts counts were significantly higher than in controls or untreated hemophiliacs in all of the three subgroups of treated hemophiliacs $(\mathrm{P}<0.001)$; in turn, the two subgroups of more intensively treated patients had significantly higher $T s$ values than hemophiliacs treated with $<20,000 \mathrm{U}$, with no significant differences between them (Fig. 2). The $\mathrm{Th} / \mathrm{Ts}$ ratios (Fig. 3) were significantly lower in the two subgroups of more intensively treated patients than in controls, untreated hemophiliacs, or the $<20,000 \mathrm{U}$ treatment group $(\mathrm{P}<0.01)$. There were no differences between treatment groups with respect to leukocyte, total lymphocyte, T-lymphocyte, or platelet counts (data not shown). 


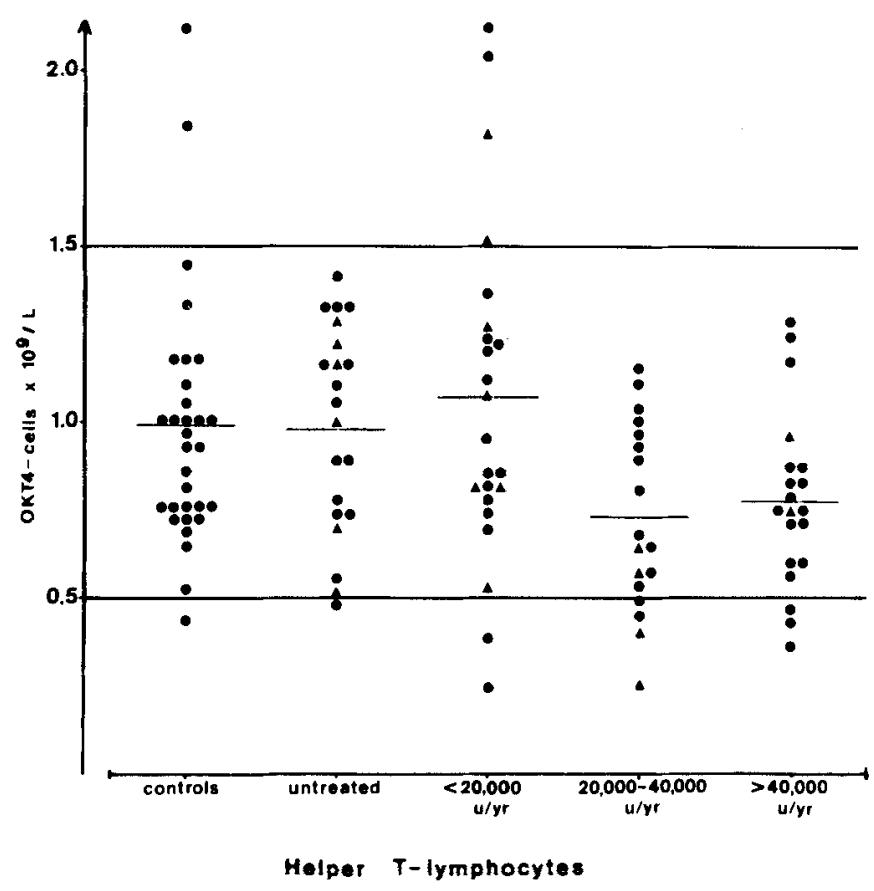

Fig. 1. OKT4 positive (helper) T-lymphocytes in healthy controls and patients with hemophilia A (circles) and B (triangles) according to total concentrate dose administed over the past year. The solid upper and lower lines indicate the normal range; the bars indicate the mean values for the different subgroups.

There was a significant nonparametric correlation between concentrate usage for each patient and Th/Ts ratios (Spearman's rho $=-0.68, \mathrm{P}<0.001$ ) (Fig. 4) and, to a lesser extent, Th counts (rho $=+0.43, \mathrm{P}<0.01$ ) and Ts counts (rho $=$ $-0.36, \mathrm{P}<0.01)$.

Investigation of the interrelationship between lymphocyte abnormalites and other variables in the hemophiliac population did not reveal any significant association between abnormalities of the T-lymphocyte subsets (expressed as Th/Ts ratios lower than 1.0) and such other variables of the population as age, HBV markers, or ALT levels (Table II). We have also evaluated whether the type of concentrate used affected the prevalence rate of alterations of lymphocyte subsets. Since the group of patients with hemophilia B treated with factor IX concentrates was small, we have divided the patients into three other dosage subgroups; no treatment, $<20,000$ and $>20,000$ $\mathrm{U} / \mathrm{yr}$. While this subdivision confirmed the association between concentrates consumption and lower ratios, there was no significant difference between factor VIII or IX users in the corresponding dosage subgroups (Table II).

\section{DISCUSSION}

Our symptomless hemophiliacs showed a moderate frequency of abnormalities of T-lymphocyte subpopulations. Lymphopenia with low Th counts, the key lymphocyte abnormality in AIDS, was seen in one patient only. We could demonstrate an absolute reduction in Th cell number in $12 \%$ of the patients, but in no instance was 


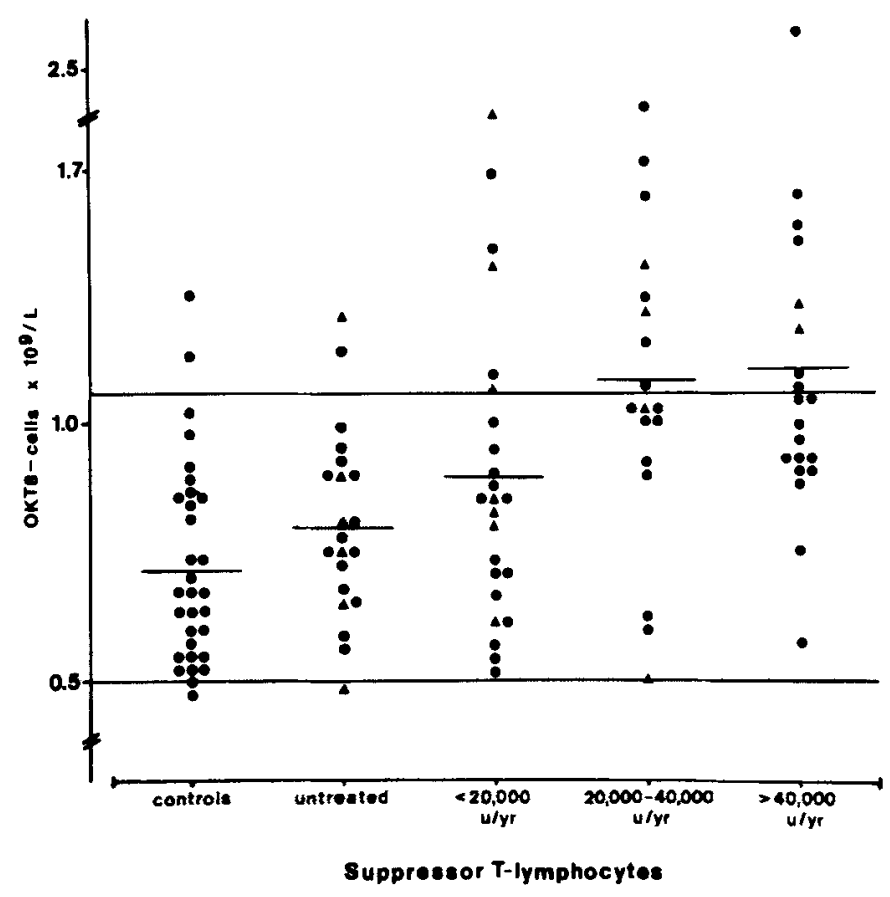

Fig. 2. OKT8 positive (suppressor) T-lymphocytes in healthy controls and patients according to total concentrate dose administered over the past year. Symbols as in Figure 1.

the decrease very pronounced (Fig. 1). Low Th/Ts ratios were mainly due to absolute or relative increases in Ts cells, with normal T-lymphocyte counts. This pattern of abnormality is common in symptomless American [7-14] and Austrian [19] hemophiliacs treated with the same commercial concentrates used by our patients, as well as in Australian [18] and Scottish [16] hemophiliacs treated exclusively with concentrates made from plasma of unpaid donors. This pattern has also been observed by several investigators, who call it "Ts augmentation," in healthy homosexual men in the United Kingdom and the United States [21-23]. A common link between these situations is the likelihood that these categories of individuals are chronically exposed to parenteral contact with allogenic proteins and multiple infectious agents. Since increased numbers of Ts cells (which include cytotoxic cells) are also found in patients recovering from common viral infections (cytomegalovirus, Epstein-Barr virus, varicella, herpes simplex) [24-26] this "abnormality" is probably really a normal response to the repeated challenge of immunoregulatory cells by antigen rather than indicative of risk to AIDS.

The most important finding in our study was the clear-cut association between abnormalities of the T-lymphocyte subpopulations and the amount of concentrate used in the year preceding the blood testing. In hemophiliacs treated with less than 20,000 $\mathrm{U} / \mathrm{yr}$, abnormalities were generally no more frequent and pronounced than in healthy controls or untreated hemophiliacs, whereas abnormalities were much more frequent and pronounced in hemophiliacs treated with annual dosages greater than $20,000 \mathrm{U}$. In addition to the higher overall prevalence of lymphocyte subset abnormalities in the groups of more intensively treated hemophiliacs, there was also a significant correlation between individual annual consumption of concentrates and the $\mathrm{Th} / \mathrm{Ts}$ ratios, the 

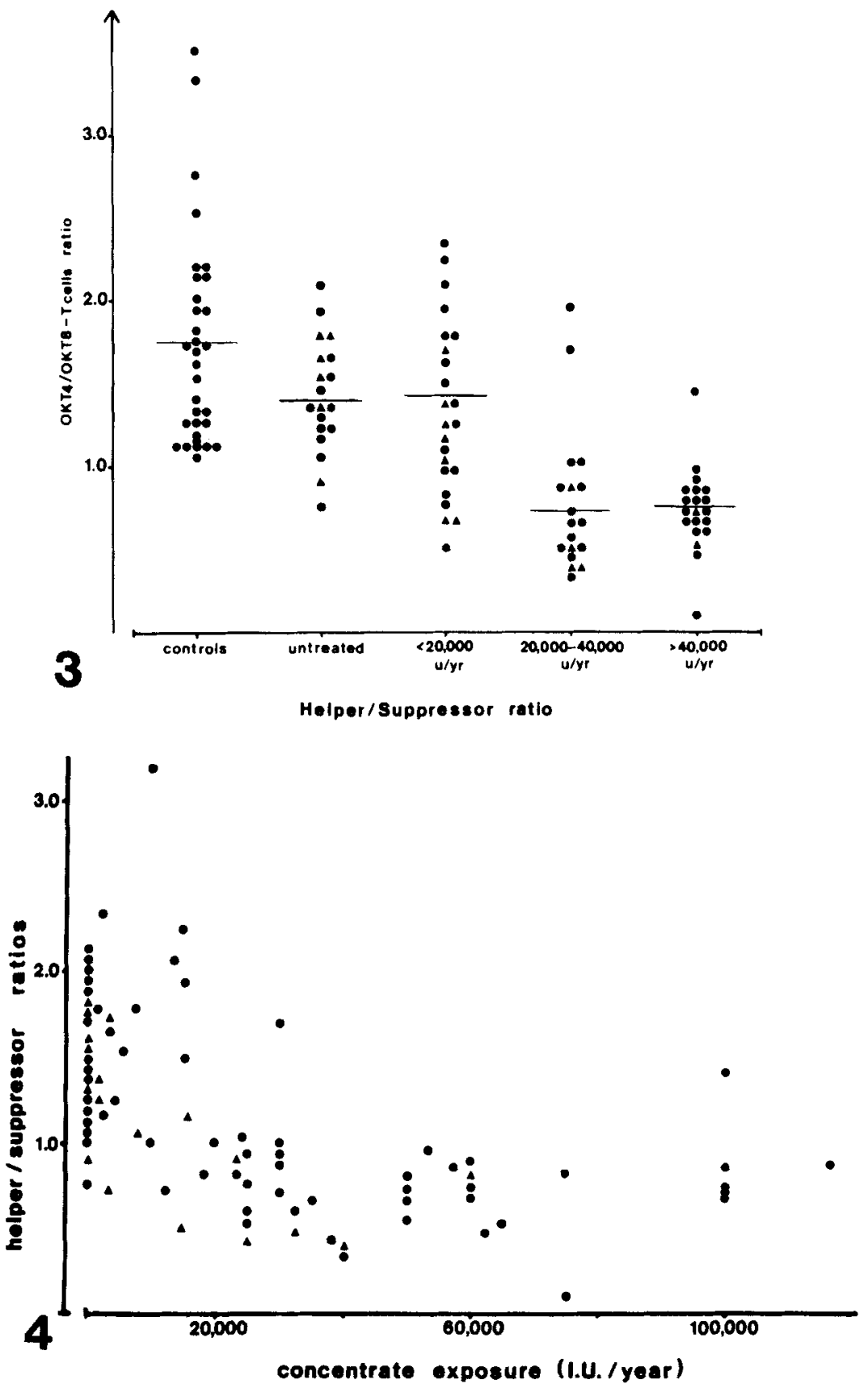

Fig. 3. Ratio of OKT4 positive (helper) T-lymphocytes to OKT8 positive (suppressor) lymphocytes in healthy controls and patients according to total concentrate dose administered over past year. Symbols as in Figure 1.

Fig. 4. Relationship to the T-helper/suppressor cell ratio (OKT4-OKT8 ratio) to concentrate used over the past year. Spearman's rank test: rho $=-0.68(\mathrm{P}<0.001)$. Symbols are as in Figure 1. 
TABLE II. T-Helper/T-Suppressor Ratios in Hemophilic Subgroups

\begin{tabular}{|c|c|c|c|c|}
\hline & No. & Mean \pm S.D. & $\begin{array}{c}\text { No. } \\
\text { abnormal }\end{array}$ & $\begin{array}{c}\text { Percent } \\
\text { abnormal }\end{array}$ \\
\hline Controls & 31 & $1.76 \pm 0.68$ & 0 & 0 \\
\hline \multicolumn{5}{|l|}{ Age } \\
\hline \multicolumn{5}{|l|}{ all hemophiliacs } \\
\hline$<10$ yrs. & 21 & $1.12 \pm 0.54$ & 11 & 52 \\
\hline $10-20 \mathrm{yrs}$ & 19 & $1.00 \pm 0.42$ & 11 & 58 \\
\hline $21-30$ yrs. & 20 & $1.02 \pm 0.66$ & 13 & 65 \\
\hline$>30$ yrs. & 23 & $1.26 \pm 0.53$ & 7 & 30 \\
\hline \multicolumn{5}{|c|}{ Amount of concentrate used } \\
\hline \multicolumn{5}{|l|}{ All hemophiliacs } \\
\hline Untreated & 21 & $1.41 \pm 0.33$ & 0 & 0 \\
\hline$>20,000 \mathrm{U} / \mathrm{yr}$ & 24 & $1.43 \pm 0.63$ & 5 & 21 \\
\hline $20,000-40,000$ & 18 & $0.73 \pm 0.33$ & 11 & 61 \\
\hline$>40,000$ & 20 & $0.75 \pm 0.25$ & 14 & 70 \\
\hline \multicolumn{5}{|c|}{$\begin{array}{l}\text { Factor VIII concentrates } \\
\text { users }\end{array}$} \\
\hline Untreated & 15 & $1.38 \pm 0.33$ & 1 & 7 \\
\hline$<20,000 \mathrm{IU} / \mathrm{yr}$ & 17 & $1.55 \pm 0.69$ & 4 & 23 \\
\hline$>20,000 \mathrm{IU} / \mathrm{yr}$ & 32 & $0.77 \pm 0.29$ & 28 & 88 \\
\hline \multicolumn{5}{|c|}{$\begin{array}{l}\text { Factor IX concentrates } \\
\text { users }\end{array}$} \\
\hline Untreated & 6 & $1.50 \pm 0.35$ & 1 & 17 \\
\hline$<20,000 \mathrm{IU} / \mathrm{yr}$ & 7 & $1.14 \pm 0.35$ & 1 & 17 \\
\hline$>20,000 \mathrm{IU} / \mathrm{yr}$ & 6 & $0.57 \pm 0.20$ & 6 & 100 \\
\hline \multicolumn{5}{|l|}{ HBV markers } \\
\hline \multicolumn{5}{|l|}{ All hemophiliacs } \\
\hline HBsAg + ve & 3 & $0.93 \pm 0.74$ & 2 & 66 \\
\hline HBsAg - ve & 80 & $1.12 \pm 0.54$ & 41 & 51 \\
\hline anti-HBs + ve & 61 & $0.97 \pm 0.47$ & 38 & 62 \\
\hline anti-HBs - ve & 22 & $1.24 \pm 0.60$ & 6 & 28 \\
\hline \multicolumn{5}{|l|}{ ALT levels } \\
\hline \multicolumn{5}{|l|}{ All hemophiliacs } \\
\hline$<50 \mathrm{U} / \mathrm{L}$ & 57 & $1.14 \pm 0.53$ & 29 & 51 \\
\hline 51-100 U/L & 15 & $1.12 \pm 0.57$ & 7 & 47 \\
\hline$>100 \mathrm{U} / \mathrm{L}$ & 11 & $0.82 \pm 0.60$ & 7 & 64 \\
\hline
\end{tabular}

$\mathrm{Th}$, and the Ts counts. It might well be, therefore, that the extent of the foreign protein load is the main determinant of the abnormalites observed in our hemophiliacs, although admittedly greater exposure to viruses cannot be disregarded in more intensively treated patients. Surprisingly, the problem of the association between the amount of concentrate administered and lymphocyte abnormalities has not been already widely investigated in hemophiliacs. Only Lee et al [7] have found significantly lower Th/Ts ratios in 47 hemophilia A patients treated with $>25,000 \mathrm{U} / \mathrm{yr}$ than in 17 patients treated with $<25,000 \mathrm{U}$. Two other studies $[7,8]$ of small groups were unable to find such correlations between concentrate consumption and lymphocyte abnormalites; in other studies $[14,19,20]$, there was a trend toward lower Th/Ts ratios with increasing concentrate consumption but the relationship was not statistically significant, probably because of the small number of cases or excessive subdivision of the patients according to concentrate consumption. Unlike in some studies $[8,10,17]$, but in agreement with others [14], another interesting finding in our study was that the fractionation method used in concentrate manufacturing was not an 
important determinant of lymphocyte abnormalities because abnormal ratios were also seen in hemophilia B patients treated with factor IX concentrates, with a similar association between large annual consumption and more pronouced abnormalities. We cannot at present explain these different findings, but it must be emphasized again that the numbers of hemophilia B patients were usually very small [8-10] in the previous studies and that only one group of investigators studied more than 20 patients [17].

Abnormal lymphocyte subpopulations per se cannot yet be used for diagnostic evidence of AIDS or its prodrome; only by longitudinal studies of asymptomatic hemophiliacs with abnormal values can the relevance of such tests to AIDS risk be established. Therefore, we cannot recommend using less than $20,000 \mathrm{U} / \mathrm{yr}$ in an attempt to prevent AIDS solely on the basis of these data. We continue our present policy of giving to the patients all the factor they need, on demand, for treatment of hemorrhages and elective surgery. However, we avoid long-term prophylaxis in an attempt to prevent all hemorrhage because there is no proof that such prophylaxis results in better prevention of hemophiliac arthropathy, while it does result in much larger concentrate consumption.

\section{REFERENCES}

1. Centers for Disease Control Task Force on Kaposi's Sarcoma and Opportunistic Infections: Epidemiologic aspects of the current outbreak of Kaposi's sarcoma and opportunistic infections. N Engl J Med 306:248-252, 1982.

2. Curran JW, Evatt BL, Lawrence DN: Acquired immune deficiency syndrome: The past as prologue. Ann Intern Med 98:401-402, 1983.

3. Editorial. Acquired immunodeficiency syndrome. Lancet 1:162-164, 1983.

4. Waterson AP: Acquired immune deficiency syndrome. Br Med J 286:743-746, 1983.

5. Gottlieb MS, Groopman JE, Weinstein WM, Fahey JL, Detels R: The acquired immunodeficiency syndrome. Ann Intern Med 99:208-220, 1983.

6. White GC, Lesesne HR: Hemophilia, hepatitis and the acquired immunodeficiency syndrome. Ann Intern Med 98:403-404, 1983.

7. Lederman MM, Ratnoff OD, Scillian JJ, Jones PK, Schacter B: Impaired cell-mediated immunity in patients with classic hemophilia. N Engl J Med 308:79-83, 1983.

8. Menitove JE, Aster RH, Casper JT, Laner SJ, Gottschall JL, Williams JE, Gill JC, Wheeler DV, Piaskowski V, Kirchner P, Montgomery RR: T-lymphocyte subpopulations in patients with classic hemophilia treated with cryoprecipitate and lyophilized concentrates. N Eng J Med 308:84-86, 1983.

9. Luban NLC, Kelleher JF, Reaman GH: Altered distribution of T-lymphocyte subpopulations in children and adolescents with hemophilia. Lancet 1:503-505, 1983.

10. Kessler CM, Schulof RS, Goldstein AL, Naylor PH, Luban NLC, Kelleher JF, Reaman GH: Abnormal T-lymphocyte subpopulations associated with transfusion of blood-derived products. Lancet 1:991, 1983.

11. Saidi P, Kirn HC: T-cell subsets in hemophilia. N Engl J Med 308:1291-1292, 1983.

12. Goldsmith JC, Moseley PL, Monick M, Brady M, Humminghake GW: T lymphocyte subpopulation abnormalities in apparently healthy patients with hemophilia. Ann Intern Med 98:294-296, 1983.

13. Landay A, Poon MC, Stagno S, Lurie A, Cooper MD: Immunologic studies in asymptomatic hemophilia patients. Relationship to the acquired immune deficiency syndrome (AIDS). J Clin Invest 71:1500-1504, 1983.

14. De Shazo RD, Andes WA, Nordberg J, Newton J, Daul C, Bozelka B: An immunologic evaluation of hemophilic patients and their wives. Relationship to the acquired immunodeficiency syndrome. Ann Intern Med 99: 159-164, 1983.

15. Jones P, Proctor S, Dickinson A, George S: Altered immunology in hemophilia. Lancet 1:120-121, 1983.

16. Ludlam CA, Carz R, Vertch SE, Steel CM: Disordered immune regulation in hemophiliacs not exposed to commercial Factor VIII. Lancet 1:1226, 1983. 
17. Lee CA, Jarrony G, Ashley J, Kernoff PBA: Plasma fractionation methods and T-cell subsets in hemophilia. Lancet 2:158-159, 1983.

18. Richard KA, Joshua DE, Campbell J, Wearne A, Hodgson J, Kronenberg H: Absence of AIDS in hemophiliacs in Australia treated from an entirely voluntary blood donor system. Lancet 2:50-51, 1983.

19. Lechner K, Niessner H, Bettelheim P, Deutsch E, Fashing I, Fuhrmann M, Hinterberger W, Korninger C, Neumann E, Liszka K, Knapp W, Mayr WR, Stingl G, Zeitlhuber U: T-cell alterations in hemophiliacs treated with commercial factor concentrates. Thromb Hemost 50:552-556, 1983.

20. Gill JC, Menitove JE, Wheeler D, Aster RH, Montgomery RR. Generalized lymphadenopathy and T-cell abnormalities in hemophilia A. J Pediatr 103:18-22, 1983.

21. Kornfield H, Vande Stouwe RA, Ready MM, Grieco MH: T-lymphocyte subpopulations in homosexual men. N Engl J Med 307:729-731, 1982.

22. Pinching AJ, Mac Manus TJ, Jeffries DJ, Moshtael O, Donaghy M, Parkin JM, Munday PE, Harris JRW: Studies of cellular immunity in male homosexuals in London. Lancet 2:126-130, 1983.

23. Fahey JL, Detels R, Gottlieb MS: Immune cell augmentation (with altered T-subset ratio) is common in healthy homosexual men. N Engl J Med 308:842-43, 1983.

24. Reinherz EL, O'Brien C, Rosenthal P, Schlossman SF: The cellular basis for viral-induced immunodeficiency: Analysis by monoclonal antibodies. J Immunol 125:1269-1274, 1980.

25. Crawford DH, Brickell P, Tidman N, McConnel I, Hoffhand AV, Janossy G: Increased number of cells with suppressor T-cell phenotype in the peripheral blood of patients with infectious mononucleosis. Clin Exp Immunol 43:291-297, 1981.

26. Camey WP, Rubin RH, Hoffman RA, Hansen WP, Healey K, Hirsch MS: Analysis of T lymphocyte subsets in cytomegalovirus mononucleosis. J Immunol 126:2114-2116, 1981. 